\title{
Condos in Russia: Socio-Economic Aspect
}

\author{
D. B. Litvintsev \\ Limited Liability Company Management Company \\ "Mayak" \\ Novosibirsk, Russia \\ denlitv@inbox.ru
}

\author{
L. A. Osmuk \\ Institute of Social Technology and Rehabilitation \\ Novosibirsk State Technical University \\ Novosibirsk, Russia
}

\author{
G. P. Litvintseva \\ Economic Theory and Applied Economics Department \\ Novosibirsk State Technical University \\ Novosibirsk, Russia
}

\begin{abstract}
The paper addresses the problem of refusal of owners of residential property in Russian condominiums from taking part in general meetings on issues relating to maintenance and use of shared property. The situation of organizations providing management of condominiums under conditions when the consumer determines the cost of maintenance and services is analyzed. In the course of analysis of secondary data (State statistics of the Russian Federation, results of the All-Russian sociological research "Awareness of Russian Citizens of the Housing and Public Utilities Reform" conducted by the AllRussia Public Opinion Research Center (VCIOM) in June 2019 and the results of the psychological research "Dormitory Density and Helping Behavior" conducted by Bickman L. and Teger A. in the USA) the authors propose a number of hypotheses which require further discussion and confirmation. The first hypothesis is related to the influence of the size of a condominium (number of apartments, floors and porches) on the refusal of owners to participate in general meetings. The second hypothesis involves the use of such an adaptive model as Beyond Budgeting (the twelve principles of which were formulated by Hope J. and Fraser P.) in the management of condominiums in order to circumvent the current restrictions on the housing and communal services market in Russia.
\end{abstract}

Keywords: urban sociology, sociology of housing, condominium, shared property, general meeting, beyond budgeting

\section{INTRODUCTION}

Condominium home ownership is an important form of housing tenure at the present time in Canada's major metropolitan areas, USA, India, China etc. [1, 2, 3, 4, 5]. Harris D.C. noted that "condominium facilitated the vertical subdivision of land and enabled a massive increase in the density of private interests" [2, p. 694].

The notorious processes of privatization of housing in the 1990s in Russia produced a new form of shared property, namely common property of owners in condominiums. In compliance with the Housing Code of the Russian Federation it includes inter-flat staircase landings, staircases, elevators, technical floors, attics and basements, roofs, bearing and nonbearing structures of the house, mechanical, electrical, sanitary-plumbing and other equipment which service more than one dwelling space in the condominium, as well as the land plot where the condominium is located with elements of residential landscaping and planting [6].

The general meeting of condominium property owners whose proceedings are also stipulated in the Housing Code of the Russian Federation forms the mechanism of making decisions on managing the condominium, maintaining the shared property and its use. The residential property owners are obligated to hold an annual meeting on issues relating to the confirmation of the cost of maintenance and upkeep of the shared property for the next year. This deprives the managing organizations of a right to increase unilaterally the tariffs (if the condominium association has not been created) and puts them as service suppliers in a situation when consumers determine the cost of these services while the State regulates their quality with its numerous Federal Laws and by-laws despite the cost approved by the owners.

As far back as 2010 based on the results of their research Ermishina A.B. and Klimenko L.V. noted that the maturity level of Russian owners of privatized housing in condominiums was insufficient for successful reforming of the housing and utilities sector and introducing new communal technologies in Russia. Most property owners are characterized by inactivity, a lack of organization, propensity for state and municipal dependency, a lack of skills of making collective decisions, mistrust of neighbors and authorities and the free-rider problem is quite urgent. The majority of tenants are inert, oriented to the wait and see attitude regarding the government organizations. They also reveal a relatively low level of trust to other tenants and have a weakly expressed 
Mostly this is only a statement of intent to correspond to the law stipulating this integration. [11, p.150].

In spite of the fact that a general meeting offers an opportunity to accommodation owners to receive useful and relevant information and knowledge about the legislative requirements, about their rights and responsibilities, as well as about various problems of the condominium, taking part in it is a weighty responsibility for owners.

Ryzhova N.P. and Zhuravskaya T.N. are sure that in the nearest years Russia will hardly be able to generate a western market model based on the private property rights as to do this a new type of citizens appropriate to market ideology, which in their opinion is a complete utopia, is needed. To achieve this not only the legislation and the material infrastructure but also the mentality of the population as a whole should be changed in the country. [12, p. 62].

The best way to educate a responsible owner is to protect citizens' property. However, this function should have been fulfilled by the government in the course of privatization of public or municipal residential housing when Russian citizens became co-owners of shared property in condominiums. But since the mid-1990s an illegal practice had been used at the level of Russian entities and in the city and settlement municipal formations when shared property of facilities owners (mostly basements) were first alienated to municipal property and then to third parties. Very often the possibility given to the owners to manage their condominium independently could not be implemented because the owners did not possess the subject of management, i.e. shared property.

Ovchinnikova N.V. reasonably remarks that first it is necessary to pay more attention to specific results related to implementing housing legislation, for example, to inform owners about the process of renovation and capital repairs of other condominiums, and second, it is necessary to enhance confidence of owners in entities and bodies exercising this legislation. To do this it is necessary to lead explanatory discussions at general meetings with representatives of not only the managing company but also of local self-government bodies, and regional operators (involved in building renovation and solid municipal waste recycling) [13, p.127].

However, using decisions of general meetings in view of the complexity of their holding (the procedure, terms, etc) it is impossible to timely respond to market fluctuations, for example, in the labor market or in the market of building and finishing materials, etc.

\section{METHODS}

The Housing Code of the Russian Federation forms the legal framework of the research.

In the course of theoretical research, the general scientific methods, namely, analysis and synthesis (generalization) and the analogue method were used. As far as sociological analysis is concerned, secondary data and the analysis of documents were used.

The following sources served as an information basis: 
TABLE I. COMMISSIONING THE TOTAL AREA OF CONDOMINIUMS BY FLOORS IN RUSSIAN FEDERATION (IN PERCENT TO 2009)

\begin{tabular}{|c|c|c|c|c|c|c|c|c|c|c|}
\hline Number of floors & $\begin{array}{c}2009 \\
\text { (thousand } \mathrm{m}^{2} \text { ) }\end{array}$ & 2010 & 2011 & 2012 & 2013 & 2014 & 2015 & 2016 & 2017 & 2018 \\
\hline 1 floor & 14214.9 & 89.36 & 92.68 & 93.14 & 96.13 & 104.99 & 98.99 & 91.13 & 84.38 & 75.45 \\
\hline 2 floors & 12647.7 & 91.76 & 99.00 & 105.18 & 111.85 & 137.96 & 136.53 & 122.08 & 132.35 & 132.74 \\
\hline 3 floors & 3647.0 & 105.46 & 117.74 & 150.32 & 190.12 & 261.59 & 259.16 & 220.38 & 212.67 & 193.07 \\
\hline 4 floors & 455.6 & 116.66 & 97.52 & 122.37 & 154.04 & 153.69 & 209.64 & 207.75 & 184.81 & 145.79 \\
\hline 5 floors & 2592.1 & 112.67 & 86.68 & 80.88 & 78.91 & 110.72 & 85.99 & 86.78 & 80.56 & 56.61 \\
\hline 6 floors & 600.2 & 97.08 & 109.83 & 92.60 & 110.86 & 169.39 & 177.91 & 179.94 & 212.56 & 147.45 \\
\hline 7 floors & 569.5 & 99.61 & 111.36 & 117.30 & 67.69 & 119.32 & 101.95 & 121.72 & 82.18 & 104.27 \\
\hline 8 floors & 474.1 & 93.44 & 92.70 & 97.15 & 119.93 & 129.53 & 120.42 & 116.81 & 170.20 & 97.55 \\
\hline 9 floors & 3932.5 & 91.32 & 92.92 & 103.16 & 111.40 & 109.99 & 98.63 & 98.18 & 72.64 & 66.74 \\
\hline 10 floors & 6257.9 & 107.07 & 98.72 & 85.79 & 83.00 & 77.54 & 75.33 & 60.45 & 66.95 & 53.34 \\
\hline 11 floors & 536.5 & 138.42 & 163.17 & 244.62 & 218.97 & 262.12 & 403.04 & 360.06 & 392.04 & 384.62 \\
\hline 12-16 floors & 5793.7 & 99.82 & 108.74 & 114.40 & 121.22 & 142.85 & 147.52 & 144.19 & 129.48 & 122.85 \\
\hline 17 floors and more & 7119.7 & 105.63 & 138.31 & 155.05 & 177.61 & 231.46 & 265.29 & 273.13 & 280.54 & 297.87 \\
\hline
\end{tabular}

- Data from the Federal State Statistics Service commissioning of total dwelling space of housing in terms of the number of storeys in the Russian Federation as of 27 March 2019 [14], as well as a comprehensive observation of the living conditions of the Russian population in 2018 [ROSSTAT 15; 16; 17; 18].

- Results of annual sociological research "Awareness of Russian Citizens of the Housing and Public Utilities Reform" conducted by VCIOM. In the course of research in June 20191.600 people at the age of 18 plus from 46 regions of Russia (130 population centers) were surveyed. The statistical error did not exceed $3.7 \%$ [19].

- Results of the research "Dormitory Density and Helping Behavior" conducted by Bickman L. and Teger A. in the USA. The study was arried out among students in big (approximately 528 people), middle (approximately 166 people) and small (approximately 58 people) women dormitories of Massachussets University in Amherst and Smith College [20, p. 472].

At the first stage of the research an experiment with lost letters scattered in the dormitory hall was carried out. The letters were sealed and stamped but did not have a return address. The experiment confirmed the hypothesis that in more densely-populated dormitories students demonstrated less helping behavior -only $63 \%$ of letters were sent while in middle and small dormitories these figures were $87 \%$ and $100 \%$ respectively [20, p. 474].

At the second stage a survey was carried out whose results showed that in more densely populated dormitories students reveal less confidence in each other, cooperate less and demonstrate less social responsibility than in less densely populated dormitories [20, p. 478].

Similar results were obtained by conducting an experiment with lost letters and inquiring students of both sexes in Pennsylvania University, which confirmed an absence of an influence of a student's sex on the helping behavior in dormitories [20, p. 485].

\section{RESULTS}

According to data provided by the Federal State Statistics Service the share of condominiums anuallly grows along with the persisting dynamics of low-rise housing construction (Table I). The fastest pace of housing commissioning in 2018 as compared to 2009 is seen in commissioning of 11-storeyed buildings (3.85 times), in the second place are 17-storeyed and more storeyed buildings (almost 3 times) and then go 3storeyed houses (almost 2 times), which shows a demand for some individuality and elitism. A decrease in commissioning of 9-10-storeyed houses is explained by the wish of developers to save costs, for example the requirement to equip apartment buildings with fire-fighting automatic controls and internal fire fighting water lines is applied to buildings higher than 9 storeys [14]. It means that it is just unprofitable for developers to build 10 -storeyed buildings to which practically the same requirements as to 17-storeyed buildings are applied.

This is one of the trends of modern urbalization in Russia despite the existing institutional, technological and economic problems of housing market development, in particular in the Novosibirsk region [21, pp. 223-224].

According to data of $2018,73.7 \%$ of all households lived in separate apartments [18]. Annual commissioning of thousands of square meters of living space in mid-rise- and multi-storeyed buildings necessitates the relevance of research relating to these both economic and socio-cultural problems.

Moreover, $39.3 \%$ of households live in multi-storeyed houses equipped with elevators while $35.2 \%$ households live in houses equipped with refuse chutes. It is necessary to note that the installation of elevators is obligotory in mid-rise and multi-storeyed houses including high-rise buildings.

Analyzing the data obtained by VCIOM in the course of surveying citizens of the Russian Federation we come to the conclusion that the housing and utilities reform implemented in the country has produced a one-side effect (Fig. 1).

Tenants in condominiums are more interested in installing individual cold and hot water meters (76\% of responders) and in replacing lamps and electric devices in apartments for energy-saving ones (75\% of respondents). 


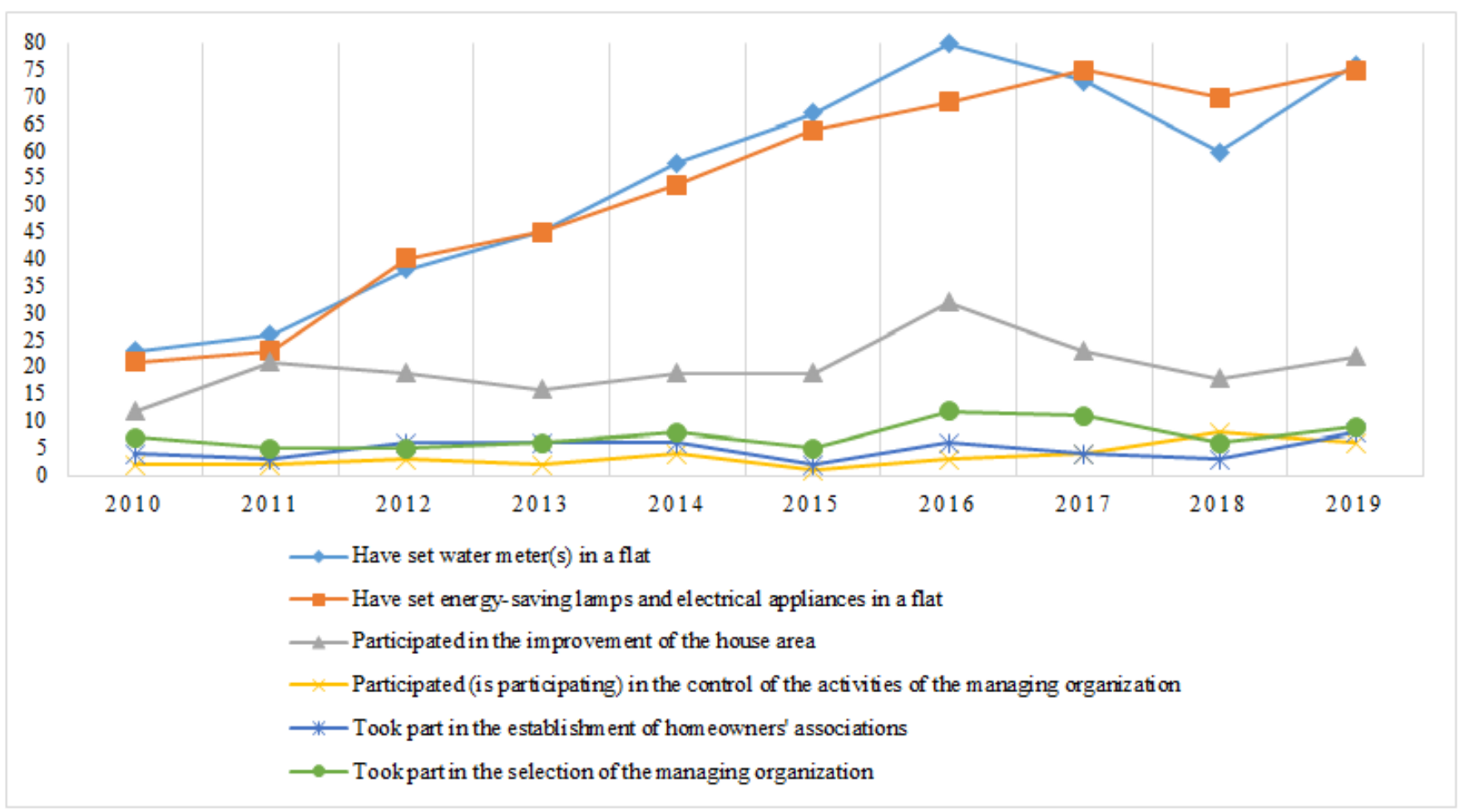

Fig. 1. The participation of Russians in the main directions of housing and communal services reform (in percent)

Tenants are much less interested in landscaping and improving the adjacent territory (22\% of respondents). Moreover, $30.6 \%$ of condominiums are not equipped with children's playgrounds, $69.4 \%$ of condominiums do not have sports grounds, $59.6 \%$ are not equipped with parking lots and $18.5 \%$ of condominiums do not even have garbage containers $[19,17]$.

The choice of the way of forming the house fund of capital repairs interested $20 \%$ of respondents and $18 \%$ of respondents took part in the general meeting on making decision on capital repairs.

Issues of choice and control of the managing company (9\% and $6 \%$ of respondents respectively), election of the Council of the condominium (20\% of respondents) and participation in creating the Condominium Partnership (8\% of respondents) actually did not interest tenants in 2019.

Besides, $13 \%$ of tenants were not interested in the life of their condominium at all as their answers to the questions offered in the survey showed.

A surge in tenants' interest in issues of choice and control of the managing company, creating the Condominium Partnership and participation in improving the adjacent territiry is first of all caused by the introduction of licensing of entrepreneurial activity in managing condominiums in 20152016.

Thus tenants of condominiums are more worried by issues of public utilities counting and reducing the costs of electric power consumed, i.e. issues of a private nature. Meanwhile issues relating to the upkeep of the shared property interest less than a quarter of people in Russia, which is a prerequisite for further study of causes of property owners' refusal from taking part in general meetings.

Despite an exceptional interest in solving individual problems condominium tenants note various unsatisfactory living conditions often caused by a poor upkeep of the shared property [15] (Fig. 2). Hence 15.4\% of households are dissatisfied with lighting of the door way, $14.9 \%$ noted the noise, dust and polluted air from the outside, $13.9 \%$ of households complain of the noise caused by their neighbors. A lesser percentage of households $(4.8 \%)$ are worried by the presence of insects and rodents. It is hardly possible to state that the tenants who did not mention the disadvantages listed in the survey $(58.9 \%)$ are content with the condition and maintenance of the shared property.

\section{DISCUSSION}

The following conclusions can be made and a number of hypotheses can be proposed as a result of the conducted theoretical research:

- The bigger the condominium (in terms of entrance hallways, the number of storeys, and apartments), the lower the responsibility level of owners concerning the shared property which is expressed in their refusal to take part in general meeting of property owners relating to issues stipulated in the Housing Code of the Russian Federation, as well as their refusal to take part in social events such as subbotniks still regularly held in Russian cities despite their certain dissatisfaction with living conditions. 


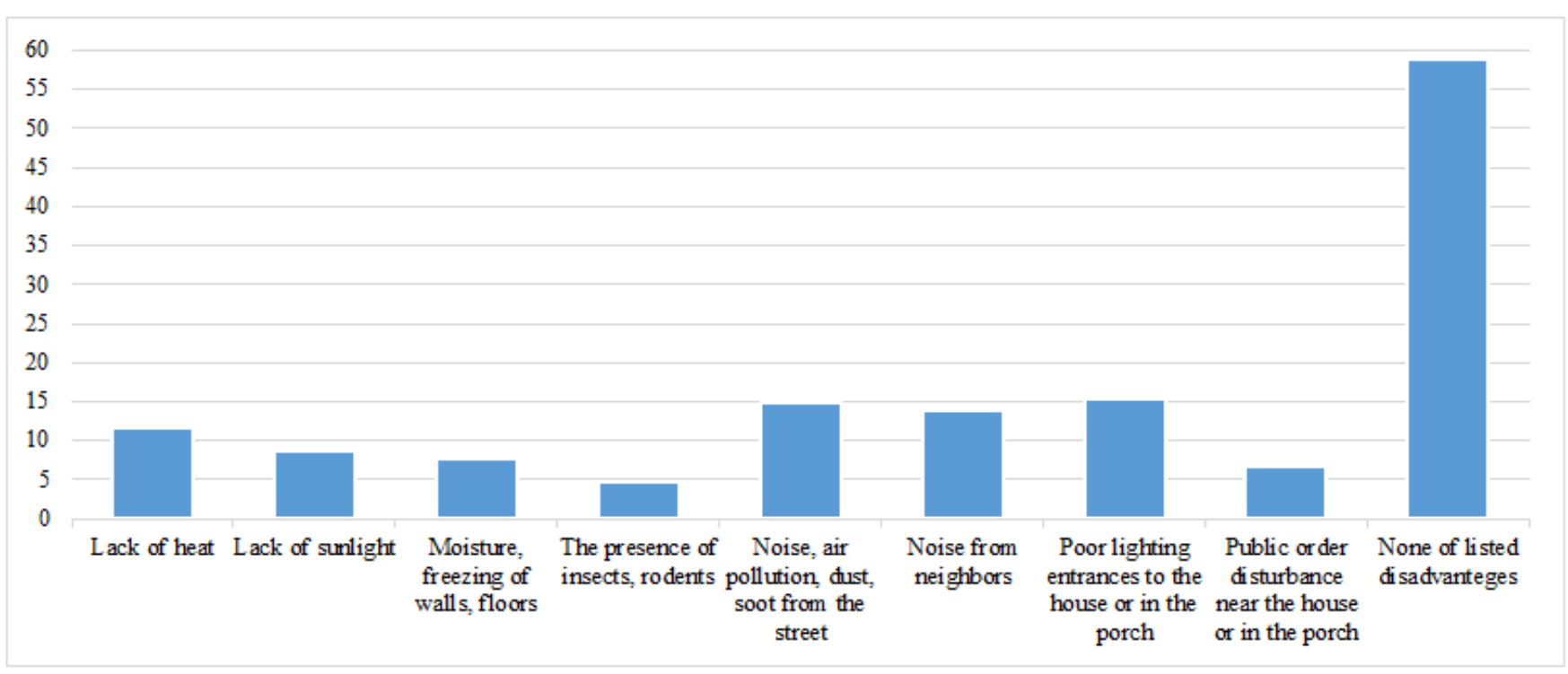

Fig. 2. Assessment of housing condition in a condominium by households (in percent)

- Under existing conditions of condominium management and regular auditing of activity by regulatory bodies, managing companies have to use the most adaptive, flexible management models (agile models such as Scrum or Kanban in software development), one of which can be the Beyond Budgetig model, i.e. management beyond budgeting whose principles were stated by Hope J. and Fraser P. [22, pp. 70, 143] are further developed by the members of the Beyond Budgeting Round Table (BBRT). In particular, Bogsnes B. sees both a revolutionary and evolution transition to this model [23, pp. 260-263].

Twelve principles of the Beyond Budgeting model include both the leadership principles and the process management principles which were specified and ranked anew at the BBRT site in March, 2016 [24]:

1) Purpose - engage and inspire people around bold and noble causes (not around short-term financial targets).

2) Values - govern through shared values and sound judgment (not through detailed rules and regulations).

3) Transparency - make information open for selfregulation, innovation, learning and control (don't restrict it).

4) Organization - cultivate a strong sense of belonging and organize around accountable teams (avoid hierarchical control and bureaucracy).

5) Autonomy - trust people with freedom to act (don't punish everyone if someone should abuse it).

6) Customers - connect everyone's work with customer needs (avoid conflicts of interest).

7) Rhythm - organize management processes dynamically around business rhythms and events (not around the calendar year only).
8) Targets - Set directional, ambitious and relative goals (avoid fixed and cascaded targets).

9) Plan and forecast - make planning and forecasting lean and unbiased processes (not rigid and political exercises).

10) Resource allocation - foster a cost conscious mind-set and make resources available as needed (not through detailed annual budget allocations).

11) Performance evaluation - evaluate performance holistically and with peer feedback for learning and development (not based on measurement only and not for rewards only).

12) Rewards - reward shared success against competition (not against fixed performance contracts).

The application of the Beyond Budgeting principles is possible within the process of transformation of the organizational culture (the systems of leadership and communication, models of behavior, etc.) proposed by Eckstein J. and Buck J. - BOSSA nova (Beyond Budgeting, Open Space, Sociocracy, Agile) [25, pp. 46-47].

Such an approach facilitates solving annual problems of budgeting (Bureaucracy, Inflexibility, Sub-optimization, Political) [26, p. 20] which inevitably arise when property owners refuse to hold an annual meeting relating to issues of increasing the amount of payment for the upkeep and repairs of communal property. This is mostly necessary under conditions of inflation, an annual growth of prices for the necessary materials and equipment used in the maintenance of an apartment house, as well as prices for services of specialized organizations maintaining the operation of elevators, fire-fighting automation systems, etc.

The second advantage of using the Beyond Budgeting principles is an opportunity to redistribute expenditure items included in the list of operations and services to upkeep communal property in the condominium in order to promptly 
[5] F. Chu, C. Chang, and T.Sing, "Collective Action Dilemmas in Condominium Management", Urban Studies, 2013, vol. 50, no. 1, pp. 128-147. example acts of vandalism). This fully corresponds to one of the key Beyond Budgeting principles, namely resource availability as and when needed (required) [22, p. 70].

Using the above advantages managing organizations can circumvent a number of key problems that they face in managing the condominiums in Russia under conditions of determining the cost of works and services by the final consumers [27].

\section{CONCLUSION}

The hypothesis of the influence of the floor space of a condominium on the attitude of owners to their shared property and their participation in general meetings proposed based on the results of this theoretical research requires further study and empirical confirmation.

When the proposed hypothesis is confirmed empirically, it is necessary to offer a proposition on making legislative changes in the present Housing Code of the Russian Federation in terms of reviewing the requirements to the procedure of general meetings and in particular the quorum for making decisions (at the moment to approve the cost of work of maintaining the shared property in a condominium despite its floor space it is necessary that the majority of owners (more than $50 \%$ of vote) should participate in decision-making.

For foreign researchers, the hypothesis put forward may become the key to understanding the socio-economic processes taking place in condominiums with a high population density, regardless of their geographical location.

The Beyond Budgeting model needs further testing in organizations involved in business activity relating to managing condominiums in the Russian Federation aimed at confirming its efficiency under Russian market conditions.

At the same time Beyond Budgeting model has already been applied in Management Company "Mayak", LLC in Novosibirsk since 2016, which has significantly reduced the organization's accounts receivable and payable, as well as reduced the number of fines from the control and oversight bodies to zero.

The experience of Managing Company "Mayak", LLC in applying Beyond Budgeting can be of great interest to organizations also involved in the management of condominiums in countries with similar housing laws.

\section{REFERENCES}

[1] M. Vachonm, "The Ever-Shrinking Condo", Canadian Journal of Urban Research, 2018, vol. 27, no. 2, pp. 37-50.

[2] D. C.Harris, "Condominium and the City: The Rise of Property in Vancouver", Law \& Social Inquiry, 2011, vol. 36, no. 3, pp. 694-726.

[3] M. Schill, I. Voicu, and J. Miller, "The Condominium versus Cooperative Puzzle: An Empirical Analysis of Housing in New York City", The Journal of Legal Studies, 2007, vol. 36, no. 2, pp. 275-324. DOI: $10.1086 / 519421$.

[4] Dh. Patel, "The evolution of elite high-rise condominiums in India: from the global to the neo-colonial?", Postcolonial Studies, 2017, vol. 20, no. 4, pp. 456-478. DOI: 10.1080/13688790.2017.
[6] "Housing Code of the Russian Federation" (26.07.2019 edition).

[7] A. Ermishina and L. Klimenko, "Searching Efficient Owners in the Apartment House", Economic Sociology, 2010, vol. 11, no. 4, pp. 105 136 (in Russian).

[8] V. N. Ilmukhin, "Urban environment as a determinant of behavioral practices: formats of sociological conceptualization", RUDN journal of sociology, 2014, no. 3, pp. 87-98 (in Russian).

[9] I. V. Dolgorukova, T. Yu. Kirilina, Yu. N. Mazaev and T. N. Yudina "Social anxiety and social fears of Russia's population: sociological dimension", Sotsiologicheskie issledovaniya, 2017, no. 2, pp. 57-66 (in Russian).

[10] V. B. Zvonovsky, D. U. Merkulova and J. V. Solovieva, "New Russian Suburban's Settler: "Aliens" or "Domectic"?", Sociological Journal, 2015, vol. 21, no. 4, pp. 61-79 (in Russian). DOI: 10.19181/socjour.2015.21.4.3066. communities in the region", Social capital, social networks, social interest in the problem of revival of local communities in Russia, Collected works, Novosibirsk, 2012, pp. 66-72 (in Russian).

[12] N. Ryzhova and T. Zhuravskaya, "Housing in Soviet and post-Soviet Russia: The Transformation of Property Relations and Everyday Resistance", Mir Rossii, 2019, vol. 28, no. 3, pp. 48-66 (in Russian). DOI: 10.17323/1811-038X-2019-28-3-48-66.

[13] N. V. Ovchinnikova, "The centrifuge of housing and communal services: a study of the behavior of citizens", Vlast, 2016, vol. 24, no. 1, pp. 124-128 (in Russian).

[14] "Commissioning of total common areas in the apartment houses by the number of storeys in the Russian Federation", Construction: Federal State Statistics Service. Available at: http://www.gks.ru/free_doc/new_site/business/stroit/stroi_et.xlsx (Accessed: 09 October 2019).

[15] Comprehensive monitoring of living conditions in the Russian Federation 2018: "Evaluation of the condition of their living premises made by households based on the locality type", Federal State Statistics Service. Available

https://www.gks.ru/free_doc/new_site/KOUZ18/Files/4.1.xlsx (Accessed: 10 October 2019).

[16] Comprehensive monitoring of living conditions in the Russian Federation 2018: "Evaluation of the house equipment made by households based on the locality type", Federal State Statistics Service. Available https://www.gks.ru/free_doc/new_site/KOUZ18/Files/5.1.xlsx (Accessed: 10 October 2019).

[17] Comprehensive monitoring of living conditions in the Russian Federation 2018: "Household evaluation of the adjacent territory made by households based on the locality type", Federal State Statistics Service.

Available https://www.gks.ru/free_doc/new_site/KOUZ18/Files/6.1.xlsx (Accessed: 10 October 2019).

[18] Comprehensive monitoring of living conditions in the Russian Federation 2018: "Distribution of households by the type of occupied living premises based on the locality type", Federal State Statistics Service. Available

https://www.gks.ru/free doc/new site/KOUZ18/Files/75.1.xlsx

[19] All-Russian sociological research conducted by the All-Russia Public Opinion Research Center (VCIOM) in June 2019 "Awareness of Russian Citizens of the Housing and Public Utilities Reform"", State Corporation Support Fund for the Housing and Utilities Sector. Available http://fondgkh.ru:443/upload/iblock/f78/f78067da1456089eb71752b8b2 dea1ee.pdf (Accessed: 10 October 2019).

[20] L. Bickman, A. Teger, Th. Gabriele, C. McLaughlin, M. Berger and E. Sunaday, "Dormitory Density and Helping Behavior", Environment and Behavior, 1973, vol. 5, pp. 465-490.
[11] L. A. Osmuk, "Consolidated policy as a condition for developing local (Accessed: 10 October 2019). 
[21] G. P. Litvintseva and O. A. Sidorenko, "Housing market and the problems of its development in the Novosibirsk region", Vestnik NSUEM, 2014, no. 1, pp. 205-225 (in Russian).

[22] J. Hope and R. Fraser, "Beyond Budgeting: How Managers Can Break Free from the Annual Performance Trap", Boston, Harvard Business Review Press, 2003.

[23] B. Bogsnes, "Implementing Beyond Budgeting: Unlocking the Performance Potential 2nd Edition", New Jersey: John Wiley \& Sons, Inc., 2016.

[24] "Beyond Budgeting Round Table" [Electronic resource]. Available at: https://bbrt.org/ (Accessed: 24 Jule 2019).
[25] J. Eckstein and J. Buck, "Company-wide Agility with Beyond Budgeting, Open Space \& Sociocracy: Survive \& Thrive on Disruption", Scotts Valley: CreateSpace Independent Publishing Platform, 2018.

[26] S. Morlidge, "The Little Book of Beyond Budgeting. A New Operation System for Organisations: What it is and Why it Works", Leicestershire: Matador, 2017.

[27] D. B. Litvintsev and N. I. Nizhal'skaya, "Condominium management under conditions of determining the cost of works and services by the consumer", Science, Technology, Innovation, Collection of scientific papers in 9 parts, Part 7, Novosibirsk: NSTU, 2019, pp. 322-325. 